\title{
KEBERADAAN CORPORATE GOVERNANCE SEBAGAI VARIABEL MODERASI PENGARUH FINANCIAL DISTRESS TERHADAP EARNINGS MANAGEMENT
}

\author{
Dody Hapsoro \\ STIE YKPN Yogyakarta \\ dodyhapsoro@gmail.com \\ Adrianus Billy Hartomo \\ STIE YKPN Yogyakarta
}

\begin{abstract}
The objective of this research is to provide empirical evidence of the effect of financial distress toward earnings management and the effect of financial distress toward earnings management that moderated by corporate governance. Financial distress consists of DISTRESS1, DISTRESS2 and DISTRESS3. Earnings management was measured by discretionary accruals using Jones Model, and corporate governance consists of three variables (board of directors, independent commissioner, and audit committee). Board of directors was measured by total board of directors in the firm included chief executive officer (CEO). Independent commissioner was measured by the proportion of independent commissioner that is total independent commissioner divided by total board of commissioner and audit committee was measured by total member of audit committee. Control variable in this research is firm size that was measured by logarithm of asset total. The population of this research is 423 non-financial companies were listed in Indonesian Stock Exchange (IDX). The research data were collected from non-financial companies annual report for the period of 2014. Based on purposive sampling method, there are 62 samples. The research hypothesis were tested by using multiple regression analysis. The results of this research in Model 1 show that firm size variable has significant relationship with earnings management, while DISTRESS1 variable, DISTRESS2 variable, and DISTRESS3 variable have no significant relationship with earnings management. The result of this research in Model 2 show that DISTRESS3 variable, independent commissioner variable, and interaction between financial distress with corporate governance variable have significant relationship with earnings management, while DISTRESS1 variable, DISTRESS2 variable, board of directors variable, audit committee variable, and firm size variable have no significant with relationship earnings management.
\end{abstract}

Keywords: financial distress, earnings management, corporate governance, and firm size 


\begin{abstract}
ABSTRAK
Tujuan dari penelitian ini adalah untuk memberikan bukti empiris pengaruh kesulitan keuangan terhadap manajemen laba dan pengaruh kesulitan keuangan terhadap manajemen laba yang dimoderasi oleh tata kelola perusahaan. Kesulitan keuangan terdiri dari DISTRESS1, DISTRESS2 dan DISTRESS3. Manajemen laba diukur dengan menggunakan akrual diskresioner yang mengaplikasikan Model Jones, dan tata kelola perusahaan terdiri dari tiga variabel (dewan direksi, komisaris independen, dan komite audit). Direksi diukur dengan menggunakan jumlah dewan direksi di dalam perusahaan termasuk chief executive officer (CEO). Komisaris independen diukur dengan menggunakan proporsi komisaris independen dimana total komisaris independen dibagi dengan total dewan komite komisaris, dan komite audit diukur dengan menggunakan jumlah anggota komite audit. Variabel kontrol dalam penelitian ini adalah ukuran perusahaan yang diukur dengan menggunakan logaritma total aset.

Populasi dalam penelitian ini adalah 423 perusahaan non keuangan yang terdaftar di Bursa Efek Indonesia (BEI). Data penelitian dikumpulkan dari laporan tahunan perusahaan non-keuangan untuk periode 2014. Berdasarkan metode purposive sampling terdapat 62 sampel penelitian. Hipotesis dalam penelitian ini diuji dengan menggunakan analisis regresi berganda. Hasil penelitian pada Model 1 menunjukkan bahwa ukuran perusahaan memiliki hubungan yang signifikan dengan manajemen laba, sedangkan variabel DISTRESS1, variabel DISTRESS2, dan variabel DISTRESS3 tidak memiliki hubungan yang signifikan dengan manajemen laba. Hasil penelitian pada Model 2 menunjukkan bahwa variabel DISTRESS3, komisaris independen, dan interaksi antara kesulitan keuangan dengan tata kelola perusahaan memiliki hubungan yang signifikan dengan manajemen laba, sedangkan variabel DISTRESS1, variabel DISTRESS2, dewan direksi, komite audit, dan ukuran perusahaan tidak memiliki hubungan signifikan dengan manajemen laba.
\end{abstract}

Kata kunci: kesulitan keuangan, manajemen laba, tata kelola perusahaan, ukuran perusahaan

\title{
PENDAHULUAN
}

Financial distress (masalah keuangan) merupakan masalah yang mendapat banyak perhatian sejak terjadinya krisis finansial pada pertengahan tahun 1997 di Asia. Financial distress dimulai ketika perusahaan tidak dapat memenuhi jadwal pembayaran atau ketika proyeksi arus kas mengindikasikan bahwa perusahaan tersebut akan segera tidak dapat memenuhi kewajibannya (Brigham \& Daves 2003).

Hasil penelitian yang dilakukan oleh Rosner (2003) terhadap 293 perusahaan bangkrut yang mewakili sekitar 2.500 perusahaan yang diobservasi menemukan bahwa manajer perusahaan yang mengalami tekanan keuangan, khususnya perusahaan dengan pelanggaran perjanjian utang akan menanggapinya dengan pilihan kebijakan akuntansi yang dapat meningkatkan laba (income increasing). Hal ini berarti bahwa manajer perusahaan yang mengalami financial distress akan cenderung melakukan earnings 
management (manajemen laba) seperti income increasing, income decreasing atau dengan teknik-teknik lainnya.

Earnings management merupakan salah satu faktor yang memengaruhi kinerja keuangan. Manajemen akan memilih metoda tertentu untuk mendapatkan laba yang sesuai dengan motivasinya. Hal ini akan berakibat pada terpengaruhnya kualitas laba yang dilaporkan, karena laba tidak sesuai dengan kinerja ekonomi yang sebenarnya (Boediono 2005). Hal tersebut sejalan dengan penelitian Scott (2009) yang menjelaskan bahwa earnings management adalah pilihan bagi manajer mengenai kebijakan akuntansi atau tindakan yang dapat berdampak pada laba dalam mencapai tujuan pelaporan laba yang lebih spesifik. Untuk mengurangi perilaku manajemen laba dan meningkatkan kualitas laporan keuangan perlu dilakukan mekanisme tata pengelolaan perusahaan yang baik. Mekanisme ini dilakukan untuk memastikan bahwa pemilik atau pemegang saham memperoleh return dari kegiatan yang dijalankan oleh agen atau manajer (Schleifer \& Vishny 1997).

Tata kelola perusahaaan yang baik (good corporate governance) telah muncul pada sekitar tahun 1970an ketika ada persoalan dalam pelaporan keuangan (Millstein 1999). Corporate governance merupakan suatu konsep yang dikemukakan dalam rangka meningkatkan kinerja perusahaan melalui supervisi atau monitoring kinerja manajemen yang sekaligus menjamin akuntabilitas manajemen terhadap stakeholder. Konsep ini diajukan dengan kerangka acuan demi terwujudnya pengelolaan perusahaan yang transparan untuk semua pemakai laporan keuangan (Nasution \& Setiawan 2007).

Penjelasan di atas menunjukkan bahwa perusahaan yang mengalami financial distress cenderung melakukan earnings management. Keberadaan corporate governance diharapkan dapat menekan kemungkinan terjadinya earnings management. Oleh karena itu dalam penelitian ini memasukkan corporate governance sebagai variabel pemoderasi yang diduga dapat memperlemah pengaruh financial distress terhadap earnings management.

Penelitian Chtourou, Bédard, dan Courteau (2001), Widari (2004) serta Nasution dan Setiawan (2007) menganalisis pengaruh proporsi komisaris independen terhadap manajemen laba. Penelitian mereka menemukan bahwa proporsi komisaris independen berpengaruh negatif signifikan terhadap manajemen laba. Artinya proporsi komisaris independen mampu mengurangi praktik manajemen laba yang terjadi di perusahaan. Penelitian tersebut berbeda dengan penelitian Siregar dan Utama (2005) serta Nuryaman (2008) yang menunjukkan bahwa jumlah dewan komisaris tidak memberikan pengaruh terhadap manajemen laba.

Penelitian Nasution dan Setiawan (2007) dengan sampel perusahaan perbankan tidak menemukan adanya pengaruh signifikan ukuran perusahaan terhadap manajemen laba. Namun Nuryaman (2008) menemukan adanya hubungan signifikan antara ukuran perusahaan manufaktur dengan praktik manajemen laba pada perusahaan manufaktur yang terdaftar di BEI. 
Lin, Li, dan Yang (2006) dalam penelitiannya menemukan bahwa ukuran komite audit berhubungan negatif dengan penyajian laba kembali. Penelitian ini didukung oleh penelitian yang dilakukan oleh Emrinaldi (2007) yang menemukan bahwa ukuran komite audit berpengaruh negatif dan signifikan terhadap kondisi financial distress. Namun penelitian Rahmat, Iskandar, dan Saleh (2009) menunjukkan hasil yang berbeda, yaitu ukuran komite audit tidak berpengaruh secara signifikan terhadap financial distress. Adanya kesenjangan serta hasil-hasil penelitian yang belum konsisten mendorong peneliti untuk melakukan penelitian lebih lanjut mengenai hubungan antara financial distress dan praktik manajemen laba pada perusahaan yang terdaftar di Bursa Efek Indonesia.

Penelitian ini merupakan pengembangan dari penelitian yang dilakukan oleh Gunawan, Rudiawarni, dan Sutanto (2014) mengenai hubungan antara financial distress dengan earnings management pada badan usaha sektor manufaktur yang terdaftar di BEI periode 2010-2012. Namun penelitian yang dilakukan ini menambahkan variabel corporate governance sebagai variabel moderasi karena berdasarkan pendapat Schleifer dan Vishny (1997) bahwa corporate governance dapat digunakan untuk mengurangi perilaku earnings management. Penelitian ini dimaksudkan untuk mengetahui pengaruh financial distress terhadap earnings management dan meneliti pengaruh financial distress terhadap earnings management yang dimoderasi oleh corporate governance.

\section{KAJIAN PUSTAKA DAN PERUMUSAN HIPOTESIS}

\section{Teori Keagenan}

Prinsip utama teori ini menyatakan adanya hubungan kerja antara pihak yang memberi wewenang (principal), yaitu investor dengan pihak yang menerima wewenang (agent), yaitu manajer dalam bentuk kontrak kerjasama (Triwahyuningtias 2012). Teori keagenan digunakan sebagai dasar untuk memahami corporate governance.

\section{Financial Distress}

Financial distress dimulai ketika perusahaan tidak dapat memenuhi jadwal pembayaran atau ketika proyeksi arus kas mengindikasikan bahwa perusahaan tersebut akan segera tidak dapat memenuhi kewajibannya (Brigham \& Daves 2003). Menurut Platt dan Platt (2002), financial distress didefinisikan sebagai tahap penurunan kondisi keuangan yang terjadi sebelum terjadinya kebangkrutan ataupun likuidasi.

\section{Earnings Management}

Healy dan Wahlen (1999) menjelaskan bahwa manajemen laba muncul ketika manajer menggunakan keputusan tertentu dalam laporan keuangan dan mengubah transaksi untuk mengubah laporan keuangan sehingga akan menyesatkan stakeholder yang ingin mengetahui kinerja ekonomi yang diperoleh perusahaan atau untuk memengaruhi hasil kontrak dengan menggunakan angka-angka akuntansi yang dilaporkan itu. Scott (2003) menemukan beberapa motivasi terjadinya manajemen laba, 
yaitu: kontrak bonus, stock price effect, faktor politik, faktor pajak, pergantian chief executive officer dan penawaran saham perdana. Menurut Setiawati \& Na'im (2000), manajemen laba dapat dilakukan dengan tiga teknik, yaitu: memanfaatkan peluang untuk membuat estimasi akuntansi, mengubah metoda akuntansi dan menggeser periode biaya atau pendapatan

\section{Corporate Governance}

The Institute Indonesia of Corporate Governance (The Indonesian Institute for Corporate Governance 2006) mendefinisikan corporate governance (CG) sebagai serangkaian mekanisme untuk mengarahkan dan mengendalikan suatu perusahaan agar operasional perusahaan berjalan sesuai dengan harapan para pemangku kepentingan (stakeholders). Mekanisme corporate governance merupakan suatu hubungan antara pihak yang mengambil keputusan dengan pihak yang melakukan kontrol atau pengawasan terhadap keputusan (Fitdini 2009).

\section{Perumusan Hipotesis}

\section{Financial Distress dan Earnings Management}

Menurut Platt dan Platt (2002), financial distress didefinisikan sebagai tahap penurunan kondisi keuangan yang terjadi sebelum terjadinya kebangkrutan ataupun likuidasi. Financial distress merupakan masalah yang cukup berat bagi perusahaan karena apabila dibiarkan dapat mengakibatkan terjadinya kebangkrutan ataupun likuidasi, sehingga hal ini dapat mendorong manajer perusahaan untuk melakukan earnings management. Healy dan Wahlen (1999) menjelaskan bahwa manajemen laba muncul ketika manajer menggunakan keputusan tertentu dalam laporan keuangan dan mengubah transaksi untuk mengubah laporan keuangan sehingga akan menyesatkan stakeholder yang ingin mengetahui kinerja ekonomi yang diperoleh perusahaan atau untuk memengaruhi hasil kontrak dengan menggunakan angka-angka akuntansi yang dilaporkan itu.

Hasil penelitian yang dilakukan oleh Rosner (2003) terhadap 293 perusahaan bangkrut yang mewakili sekitar 2.500 perusahaan yang diobservasi menemukan bahwa manajer perusahaan yang mengalami tekanan keuangan, khususnya perusahaan dengan pelanggaran perjanjian utang, akan menanggapinya dengan pilihan kebijakan akuntansi yang dapat meningkatkan laba (income increasing). Berdasarkan penelitian yang dilakukan Rosner (2003) dapat ditarik kesimpulan bahwa perusahaan yang mengalami financial distress akan menanggapinya dengan melakukan earnings management, baik income increasing maupun income decreasing.

Berdasarkan uraian di atas, dapat dirumuskan hipotesis pertama sebagai berikut:

H1: Financial distress berpengaruh positif terhadap earnings management 


\section{Financial Distress, Earnings Management, dan Corporate Governance}

Pada umumnya sinyal terjadinya financial distress terlihat dari pelanggaran perusahaan atau perjanjian utang dengan pihak kreditor serta pengurangan atau penghapusan dalam membayar dividen (Fitdini 2009). Adanya financial distress dapat memicu munculnya praktik earnings management yang dilakukan oleh manajer, seperti income increasing, income decreasing atau dengan teknik-teknik lainnya. Hal tersebut sesuai dengan penelitian yang dilakukan oleh Rosner (2003) dan DeAngelo, DeAngelo, dan J.Skinner (1994).

Gunawan et al. (2014) menganalisis hubungan antara financial distress dengan earnings management dengan menggunakan enam variabel kontrol, yaitu size, leverage, operating cash flow, audit quality, kepemilikan saham dan growth. Berdasarkan hasil penelitian ditunjukkan bahwa pada hipotesis pertama ditemukan variabel distress 1 yang ditandai dengan net income negatif memiliki hubungan negatif signifikan dengan earnings management. Pada hipotesis kedua ditemukan bahwa variabel distress 2 yang ditandai dengan working capital negatif memiliki hubungan yang tidak signifikan dengan earnings management. Sedangkan pada hipotesis ketiga ditemukan bahwa variabel distress 3 yang ditandai dengan net income dan working capital negatif memiliki hubungan positif signifikan dengan earnings management. Dari enam variabel kontrol, hanya variabel size dan leverage yang memiliki hubungan signifikan dengan earnings management.

Earnings management diyakini muncul sebagai konsekuensi langsung dari upayaupaya manajer atau pembuat laporan keuangan untuk melakukan manajemen informasi akuntansi, khususnya earnings, demi kepentingan pribadi dan atau perusahaan (Gumanti 2003). Untuk mengurangi perilaku manajemen laba dan meningkatkan kualitas laporan keuangan diperlukan mekanisme tata kelola perusahaan yang baik. Mekanisme ini dilakukan untuk memastikan bahwa pemilik atau pemegang saham memperoleh pengembalian (return) dari kegiatan yang dijalankan oleh agen atau manajer (Schleifer dan Vishny 1997).

Corporate governance (CG) merupakan tata kelola perusahaan yang menjelaskan hubungan antara berbagai partisipan dalam perusahaan yang menentukan arah dan kinerja perusahaan (Monks \& Minow 2001). Bangun dan Vincent (2008) menganalisis hubungan antara komponen GCG dengan manajemen laba dan kinerja keuangan. Berdasarkan hasil penelitian ditunjukkan bahwa kepemilikan institusional memiliki hubungan negatif dengan manajemen laba dan manajemen laba memiliki hubungan negatif dengan kinerja keuangan.

Penelitian Chtourou, Bédard, dan Courteau (2001), Widari (2004) serta Nasution dan Setiawan (2007) menganalisis pengaruh proporsi komisaris independen terhadap manajemen laba. Penelitian mereka menemukan bahwa proporsi komisaris independen berpengaruh negatif signifikan terhadap manajemen laba. Artinya proporsi komisaris independen mampu mengurangi praktik manajemen laba yang terjadi di perusahaan. 
Berdasarkan uraian di atas, dapat dirumuskan hipotesis kedua sebagai berikut:

H2: Corporate governance berpengaruh negatif terhadap hubungan financial distress dan earnings management

\section{METODA PENELITIAN}

\section{Unit Analisis}

Unit analisis yang digunakan dalam penelitian ini adalah perusahaan nonkeuangan yang terdaftar di Bursa Efek Indonesia Periode 2014.

\section{Klasifikasi Variabel Penelitian}

\section{Variabel Dependen}

Variabel dependen dalam penelitian ini adalah earnings management yang diukur dengan menggunakan proksi discretionary accruals yang dihitung dengan menggunakan Jones model. Tahapan dalam menghitung discretionary accruals adalah sebagai berikut:

$T A C C_{i t}=N I_{i t}-O C F_{i t}$ 1

$\operatorname{TACC}_{i t} / T A_{i, t-1}=\alpha_{1}\left(1 / T A_{i, t-1}\right)+\alpha_{2}\left(\Delta R E V_{i t} / T A_{i, t-1}\right)+\alpha_{3}\left(P P E_{i t} / T A_{i, t-1}\right)+\varepsilon_{t}$

Kedua persamaan regresi tersebut menunjukkan bahwa NDACC dihitung dengan memasukkan kembali koefisien $\alpha_{1}, \alpha_{2}$, dan $\alpha_{3}$ ke persamaan sebagai berikut:

$N D A C C_{i t}=\alpha_{1}\left(1 / T A_{i, t-1}\right)+\alpha_{2}\left(\Delta R E V_{i t} / T A_{i, t-1}\right)+\alpha_{3}\left(P P E_{i t} / T A_{i, t-1}\right)$

Selanjutnya dapat dihitung nilai discretionary accruals sebagai berikut:

$D_{A C C}=\left(T A C C_{i t} / T A_{i, t-1}\right)-N D A C C_{i t}$

Keterangan:

TACC $_{\text {it }}=$ Total accruals perusahaan i pada periode $\mathrm{t}$

$N I_{i t} \quad=$ Net Income perusahaan i pada periode $\mathrm{t}$

$O C F_{i t}=$ Operating cash flows perusahaan i pada periode $\mathrm{t}$

$T A_{i, t-1}=$ Total assets perusahaan i pada periode $\mathrm{t}-1$

$\triangle R E V_{i t}=$ Perubahan pendapatan perusahaan i pada periode $\mathrm{t}$

$P P E_{i t}=$ Property, plan, dan equipment perusahaan i pada periode $\mathrm{t}$

$\varepsilon_{t} \quad=$ Error term

$D A C C_{i t}=$ Discretionary accruals perusahaan i pada periode $\mathrm{t}$

$N D A C C_{i t}=$ Non-discretionary accruals perusahaan i pada periode $\mathrm{t}$

\section{Variabel Independen}

Variabel independen dalam penelitian ini adalah financial distress. Pengklasifikasian dan perhitungan nilai diskriminan badan usaha ke dalam kategori badan usaha non financial distress dan badan usaha financial distress menggunakan adaptasi dari McKeown et al. (1991), Hopwood et al. (1994), serta Mutchler et al. (1997). Perusahaan dapat diklasifikasikan masuk dalam kategori financial distress apabila mengalami salah satu kondisi berikut ini. 
1. Mengalami net income negatif selama tahun berjalan (distress 1)

2. Modal kerja negatif selama tahun berjalan (distress 2)

3. Baik modal kerja dan net income negatif selama tahun berjalan (distress 3)

Badan usaha yang memenuhi salah satu dari ketiga kriteria di atas diberi nilai 1 dan nilai 0 apabila badan usaha tidak memenuhi salah satu dari ketiga kriteria di atas.

\section{Variabel Moderasi}

Variabel moderasi dalam penelitian ini adalah corporate governance. Corporate governance terdiri atas dewan direksi, komisaris independen dan komite audit.

\section{Ukuran Dewan Direksi}

Dalam penelitian ini, ukuran dewan direksi diukur dengan menghitung jumlah anggota dewan direksi yang ada dalam perusahaan pada periode $\mathrm{t}$, termasuk CEO (Wardhani 2006).

\section{Komisaris Independen}

Proporsi komisaris independen dihitung dengan cara:

Proporsi komisaris independen $=\frac{x}{y}$

Keterangan:

$\mathrm{X}=$ Jumlah komisaris independen pada sebuah perusahaan pada periode $\mathrm{t}$

$\mathrm{Y}=$ Total jumlah komisaris pada sebuah perusahaan pada periode $\mathrm{t}$

\section{Ukuran Komite Audit}

Dalam penelitian ini, komite audit diukur dengan jumlah anggota di dalam komite audit.

\section{Variabel Kontrol}

Dalam penelitian ini variabel kontrol yang digunakan adalah ukuran perusahaan (size). Pengukuran variabel ukuran perusahaan dilakukan dengan menggunakan logaritma dari total asset.

\section{Uji Asumsi Klasik}

Pengujian normalitas bertujuan untuk menguji apakah model regresi variabel pengganggu atau residual memiliki distribusi normal. Ada dua cara untuk mendeteksi apakah residual berdistribusi normal atau tidak, yaitu dengan analisis grafik dan uji statistik (Ghozali 2005). Uji statistik yang digunakan adalah uji statistik non-parametrik K-S (Kolmogorov-Smirnov).

Ghozali (2007) menjelaskan bahwa uji autokorelasi bertujuan untuk menguji apakah di dalam suatu model regresi linier terdapat korelasi antara kesalahan pengganggu pada periode $t$ dengan kesalahan pengganggu pada periode $t-1$. Pendeteksian ada tidaknya autokorelasi dapat dilakukan dengan menggunakan uji Durbin Watson (Durbin Watson test). 
Tujuan uji heteroskedastisitas adalah untuk menguji apakah dalam model regresi terjadi ketidaksamaan varian dari residual satu pengamatan ke pengamatan lainnya (Ghozali 2007). Dalam penelitian ini peneliti menggunakan uji Glejser untuk mendeteksi adanya masalah dalam model regresi.

\section{Analisis Korelasi}

Analisis korelasi digunakan untuk menganalisis hubungan (korelasi) antara dua variabel. Keeratan hubungan antara dua variabel yang diamati dapat dilihat dari besarnya koefisien korelasinya. Besarnya koefisien korelasi antara dua variabel berkisar dari -1 sampai dengan +1 . Jika menggunakan kriteria nilai absolut, besarnya koefisien korelasi antara dua variabel berkisar dari 0 sampai dengan 1 .

\section{ANALISIS DAN PEMBAHASAN}

\section{Deskripsi Objek Penelitian}

Sampel yang digunakan dalam penelitian ini dipilih secara purposive sampling. Proses pemilihan sampel berdasarkan kriteria yang telah ditetapkan dapat dilihat pada tabel di bawah ini.

Tabel 1

Proses Pemilihan Sampel Berdasarkan Kriteria

\begin{tabular}{|c|c|c|}
\hline No & Kriteria & Jumlah Perusahaan \\
\hline 1. & $\begin{array}{l}\text { Total perusahaan yang terdaftar secara aktif di Bursa Efek } \\
\text { Indonesia pada periode pelaporan tahun } 2014\end{array}$ & 532 \\
\hline 2. & Merupakan perusahaan keuangan & $(109)$ \\
\hline 3. & Merupakan perusahaan non-keuangan & 423 \\
\hline 4. & $\begin{array}{l}\text { Perusahaan yang tidak mempublikasikan laporan tahunan } \\
\text { melalui website www.idx.co.id sampai } 31 \text { Juli } 2015\end{array}$ & $(359)$ \\
\hline 5 . & $\begin{array}{l}\text { Perusahaan yang mempublikasikan laporan tahunan melalui } \\
\text { website www.idx.co.id sampai } 31 \text { Juli } 2015\end{array}$ & 64 \\
\hline 6. & Data outlier & (2) \\
\hline \multicolumn{2}{|c|}{ Jumlah sampel akhir } & 62 \\
\hline \multicolumn{2}{|c|}{ Tahun pengamatan } & 1 \\
\hline \multicolumn{2}{|c|}{ Jumlah pengamatan } & 62 \\
\hline
\end{tabular}

Berdasarkan kriteria sampel yang telah ditetapkan, diperoleh sebanyak 62 perusahaan yang digunakan sebagai sampel penelitian dan dikelompokkan ke dalam 3 kelompok besar industri non-keuangan, yaitu: industri umum, industri properti dan industri infrastruktur. Distribusi sampel penelitian berdasarkan 3 kelompok besar industri dapat dilihat pada tabel di bawah ini.

Tabel 2

Distribusi Perusahaan Sampel Berdasarkan Kelompok Industri Non-Keuangan

\begin{tabular}{clc}
\hline No & Kelompok Industri & Jumlah \\
\hline 1. & Industri Umum & 54 \\
2. & Industri Properti & 7 \\
3. & Industri Infrastruktur & 1 \\
\hline & Jumlah & 62 \\
\hline
\end{tabular}

Sumber: BEI 


\section{Analisis Statistik Deskriptif}

Tabel 3

Statistik Deskriptif

\begin{tabular}{lccccc}
\hline & N & Minimum & Maximum & Mean & Std. Deviation \\
\hline DISTRESS1 & 62 & 0 & 1 & 0,18 & 0,385 \\
DISTRESS2 & 62 & 0 & 1 & 0,08 & 0,275 \\
DISTRESS3 & 62 & 0 & 1 & 0,03 & 0,178 \\
DIR_SIZE & 62 & 2 & 13 & 5,56 & 2,215 \\
IND_COM & 62 & 0,000 & 0,800 & 0,39355 & 0,132617 \\
AUD_COM & 62 & 2 & 4 & 2,95 & 0,459 \\
DACC & 62 & $-0,16353$ & 0,14716 & 0,0000000 & 0,06369641 \\
FD_CG & 62 & 0,000 & 40,200 & 2,6538710 & 7,08047682 \\
SIZE & 62 & 9,78 & 14,37 & 12,4958 & 0,83690 \\
\hline SUZ
\end{tabular}

Sumber: Hasil pengolahan data sekunder

\section{Pengujian Asumsi Klasik}

Dalam penelitian ini uji multikolinearitas diganti dengan menggunakan uji correlation bivariate. Uji normalitas dalam penelitian ini menggunakan uji KolmogorovSmirnov (K-S). Lampiran 2 menyajikan hasil pengujian Kolmogorov-Smirnov Model 1 dan Model 2 dalam penelitian ini.

Hasil uji Kolmogorov-Smirnov pada Model 1 menunjukkan nilai 0,869 dan signifikan pada nilai 0,437. Sedangkan hasil uji Model 2 menunjukkan nilai 0,735 dan signifikan pada nilai 0,652 . Kedua hasil tersebut menunjukkan nilai signifikansi di atas 0,05 , berarti bahwa residual model regresi dalam penelitian ini berdistribusi normal .

Hasil regresi residual kuadrat dengan variabel independen ditunjukkan dengan nilai signifikansi. Dalam penelitian ini, peneliti menggunakan tingkat signifikansi 0,05. Lampiran 3 menyajikan hasil pengujian heteroskedastisitas.

Berdasarkan nilai signifikansi variabel-variabel independen pada Model 1 dan Model 2 tersebut dapat dilihat bahwa probabilitas signifikansi semua variabel independen di atas tingkat kepercayaan 5\%. Hal ini menunjukkan bahwa tidak terjadi heteroskedastisitas dalam penelitian ini.

Selanjutnya, dilakukan uji autokorelasi dengan menggunakan Durbin-Watson statistic (DW). Lampiran 4 menyajikan hasil pengujian autokorelasi Model 1 dan Model 2.

Hasil pengujian Model 1 menunjukkan nilai Durbin-Watson statistic 2,057, sedangkan du senilai 1,727 dan 4-du senilai 2,273. Hasil pengujian Model 2 menunjukkan nilai Durbin-Watson statistic 1,903 sedangkan du senilai 1,894 dan 4-du senilai 2,106. Hal ini menunjukkan bahwa nilai DW terletak diantara du dan 4-du sehingga dapat disimpulkan bahwa model regresi dalam penelitian ini bebas dari autokorelasi. 


\section{Analisis Regresi Linear Berganda}

Analisis regresi linear berganda digunakan untuk menguji hipotesis tentang pengaruh variabel independen secara simultan maupun parsial. Hasil analisis regresi Model 1 dan Model 2 dapat dilihat pada Tabel 4.23 (Lampiran 4)

Dari tabel 10 dapat dibuat persamaan regresi sebagai berikut:

$D A C_{i t}=-0,239-0,036(\text { DISTRESS } 1)_{i t}-0,030(\text { DISTRESS } 2)_{i t}-0,053(\text { DISTRESS3 })_{i t}+0,020$ $(S I Z E)_{i t}$

Hasil di atas menunjukkan bahwa variabel DISTRESS1, variabel DISTRESS2, dan variabel DISTRESS3 berpengaruh negatif terhadap earnings management, sedangkan variabel SIZE berpengaruh positif terhadap earnings management.

Dari tabel 4.24 (Lampiran 4) dapat dibuat persamaan regresi sebagai berikut:

$D A C_{i t}=-0,194+0,117(\text { DISTRESS } 1)_{i t}+0,150(\text { DISTRESS } 2)_{i t}+0,497(\text { DISTRESS3 })_{i t}+$ $0,003\left(D I R \_S I Z E\right)_{i t}+0,227\left(I N D \_C O M\right)_{i t}-0,017\left(A U D \_C O M\right)_{i t}-0,024[(D I S T R E S S 1+$ DISTRESS $\left.2+D I S T R E S S 3) *\left(D I R \_S I Z E+I N D \_C O M+A U D \_C O M\right)\right]_{i t}+0,012(S I Z E)_{i t}$ 7

Hasil di atas menunjukkan bahwa variabel DISTRESS1, variabel DISTRESS2, variabel DISTRESS3, variabel DIR_SIZE, variabel IND_COM dan variabel SIZE berpengaruh positif terhadap earnings management, sedangkan variabel AUD_COM dan variabel FD_CG berpengaruh negatif terhadap earnings management.

\section{Hasil Pengujian Hipotesis}

Hasil pengujian hipotesis dalam penelitian ini dapat dilihat pada Tabel 4.25 (Lampiran 4).

Hasil pengujian hipotesis pertama dengan menggunakan uji t-test menunjukkan bahwa variabel DISTRESS1 tidak berpengaruh signifikan terhadap variabel earnings management. Hal tersebut berarti bahwa semakin tinggi atau rendah tingkat net income negatif yang dialami perusahaan selama tahun berjalan tidak berpengaruh terhadap earnings management. Ini menunjukkan bahwa ketika net income perusahaan negatif tidak berpengaruh bagi manajemen untuk melakukan earnings management karena perhatian para investor tidak hanya pada net income saja, tetapi juga faktor-faktor lain seperti modal kerja (working capital), tata kelola perusahaan yang baik (GCG), corporate social responsibility (CSR) atau faktor-faktor lainnya. Hasil uji tersebut bertentangan dengan penelitian Gunawan et al. (2014) yang menemukan bahwa variabel DISTRESS1 berpengaruh negatif dan signifikan terhadap earnings management.

Variabel DISTRESS2 yang diukur dengan kondisi keuangan perusahaan dengan modal kerja negatif selama tahun berjalan tidak berpengaruh signifikan terhadap earnings management. Hal ini menunjukkan bahwa ketika modal kerja perusahaan negatif tidak berpengaruh terhadap manajemen untuk melakukan earnings management karena perhatian investor lebih pada net income. Hal ini sesuai dengan penelitian Ridwan (2001) yang mengatakan bahwa pada praktiknya yang banyak menjadi perhatian investor dan 
calon investor dalam laporan keuangan hanya terpusat pada laba perusahaan karena pada dasarnya laba yang dilaporkan oleh manajemen merupakan sinyal bagi para pengguna laporan keuangan terutama mengenai laba perusahaan di masa mendatang.

Variabel DISTRESS3 yang diukur dengan kondisi keuangan perusahaan yang mengalami net income maupun modal kerja negatif selama tahun berjalan terbukti tidak berpengaruh signifikan terhadap earnings management. Hal ini menunjukkan bahwa ketika net income maupun modal kerja perusahaan negatif tidak berpengaruh terhadap manajemen untuk melakukan earnings management karena selain net income dan modal kerja masih banyak faktor lain yang diperhatikan investor sebelum berinvestasi, misalnya GCG. Dengan adanya GCG, investor akan lebih percaya bahwa laporan keuangan yang disajikan sesuai dengan kondisi yang sebenarnya, sehingga hal ini akan mendorong investor untuk berinvestasi pada perusahaan yang memiliki GCG. Hasil pengujian ini bertentangan dengan penelitian Gunawan et al. (2014) yang menemukan bahwa variabel DISTRESS3 berpengaruh positif dan signifikan terhadap earnings management.

Variabel SIZE yang diukur dengan menggunakan logaritma dari total aset berpengaruh positif signifikan terhadap earnings management. Hal ini menunjukkan bahwa semakin besar ukuran perusahaan, semakin besar kemungkinan terjadinya praktik earnings management dan sebaliknya. Hal tersebut mungkin disebabkan karena perusahaan yang berukuran besar akan menanggung biaya politik yang besar. Oleh karena itu perusahaan besar memiliki motivasi untuk melakukan earnings management dengan menurunkan laba agar dapat menurunkan biaya politiknya. Hasil penelitian ini bertentangan dengan penelitian Gunawan et al. (2014) yang menemukan bahwa SIZE berpengaruh negatif signifikan terhadap earnings management.

Hasil pengujian hipotesis kedua yang menggunakan uji $t$-test menunjukkan bahwa variabel DISTRESS1 yang pengukurannya adalah ketika kondisi keuangan perusahaan mengalami net income negatif selama tahun berjalan tidak berpengaruh signifikan terhadap earnings management. Hal tersebut menunjukkan bahwa semakin tinggi atau rendah tingkat net income negatif yang dialami perusahaan selama tahun berjalan tidak berpengaruh terhadap earnings management. Ini menunjukkan bahwa ketika net income perusahaan negatif tidak berpengaruh bagi manajemen untuk melakukan earnings management karena perhatian para investor tidak hanya pada net income saja, tetapi juga faktor-faktor lain seperti modal kerja (working capital), tata kelola perusahaan yang baik (GCG), CSR atau faktor-faktor lainnya. Hasil uji tersebut bertentangan dengan penelitian Gunawan et al. (2014) yang menemukan bahwa variabel DISTRESS1 berpengaruh negatif dan signifikan terhadap earnings management.

Variabel DISTRESS2 yang diukur dengan kondisi keuangan perusahaan dengan modal kerja selama tahun berjalan negatif tidak berpengaruh signifikan terhadap earnings management. Hal ini menunjukkan bahwa ketika modal kerja perusahaan negatif tidak berpengaruh bagi manajemen untuk melakukan earnings management karena perhatian investor lebih pada net income. Hal ini sesuai dengan penelitian Ridwan (2001) yang mengatakan bahwa pada praktiknya yang banyak menjadi perhatian investor dan calon investor dalam laporan keuangan hanya terpusat pada laba perusahaan karena pada 
dasarnya laba yang dilaporkan oleh manajemen merupakan sinyal bagi para pengguna laporan keuangan terutama mengenai laba perusahaan di masa mendatang.

Variabel DISTRESS3 yang diukur dengan kondisi keuangan perusahaan yang mengalami net income maupun modal kerja negatif selama tahun berjalan terbukti berpengaruh positif signifikan terhadap earnings management. Hal ini menunjukkan bahwa perusahaan yang semakin distress, maka discretionary accruals akan semakin naik. Dengan kata lain, berarti bahwa manajemen pada perusahaan yang mengalami net income maupun modal kerja negatif selama tahun berjalan cenderung melakukan earnings management untuk meningkatkan laba (income increasing). Tindakan manajemen perusahaan tersebut mungkin dilakukan karena perusahaan telah mengalami kerugian dan jumlah utang lancar melebihi aset lancar yang dimiliki perusahaan selama tahun berjalan, sehingga perusahaan tidak mampu untuk menutupi utang yang besar tersebut. Hal ini menunjukkan bahwa apabila modal kerja juga negatif, maka perusahaan tidak dapat mengakui biaya-biaya tahun depan sebagai biaya-biaya pada saat ini, karena pengakuan biaya yang semakin besar di sisi lain akan menyebabkan nilai aset lancar semakin berkurang. Sebagai contoh, apabila perusahaan memperbesar estimasi piutang tak tertagih, maka biaya yang diakui akan semakin besar, namun di sisi lain dapat menyebabkan nilai piutang bersih semakin berkurang dan aset lancar juga menurun sehingga modal kerja akan semakin turun (Gunawan, Rudiawarni, \& Sutanto 2014). Hasil pengujian ini mendukung penelitian Gunawan et al. (2014) yang menemukan bahwa variabel DISTRESS3 berpengaruh positif dan signifikan terhadap earnings management.

Variabel ukuran dewan direksi yang diukur dengan menghitung jumlah anggota dewan direksi yang ada dalam perusahaan terbukti tidak berpengaruh signifikan terhadap earnings management. Hal ini menunjukkan bahwa jumlah anggota dewan direksi yang ada dalam perusahaan tidak berpengaruh bagi manajemen untuk melakukan earnings management. Hal ini menunjukkan bahwa proses monitoring yang dilakukan oleh dewan direksi belum efektif sehingga pada akhirnya tidak mampu meningkatkan kualitas laporan keuangan. Penelitian ini konsisten dengan penelitian Dechow et al. (1996) dan Widyaningdyah (2001) yang menyatakan bahwa dewan direksi tidak berpengaruh terhadap manajemen laba.

Variabel komisaris independen terbukti berpengaruh positif signifikan terhadap earnings management. Hal ini menunjukkan bahwa semakin banyak komisaris independen, maka earnings management akan semakin tinggi. Hasil ini sesuai dengan hasil penelitian Ujiyantho dan Agus Pramuka (2007). Hal ini dapat menjelaskan bahwa penambahan anggota komisaris independen hanya sekedar memenuhi ketentuan formal, sementara pemegang saham mayoritas masih memegang peranan penting sehingga kinerja dewan komisaris tidak meningkat bahkan menurun (Boediono 2005).

Variabel ukuran komite audit yang diukur dengan jumlah anggota komite audit terbukti tidak berpengaruh signifikan terhadap earnings management. Hal ini menunjukkan bahwa jumlah anggota di dalam komite audit tidak berpengaruh bagi manajemen untuk melakukan earnings management. Penelitian ini konsisten dengan 
penelitian Widari (2004) serta Siregar dan Utama (2005) yang menemukan bahwa keberadaan komite audit tidak terbukti efektif mengurangi manajemen laba. Hal ini disebabkan karena pengangkatan komite audit oleh perusahaan hanya dilakukan untuk pemenuhan regulasi, bukan dimaksudkan untuk menegakkan GCG di perusahaan.

Variabel interaksi antara financial distress dengan corporate governance terbukti berpengaruh negatif signifikan terhadap earnings management. Hal tersebut menunjukkan bahwa keberadaan corporate governance dapat mengurangi pengaruh financial distress terhadap earnings management karena keberadaan corporate governance dapat meningkatkan kinerja perusahaan melalui supervisi atau monitoring terhadap kinerja manajemen yang sekaligus menjamin akuntabilitas manajamen terhadap stakeholder.

Variabel SIZE yang diukur dengan menggunakan logaritma dari total aset tidak berpengaruh signifikan terhadap earnings management. Hal tersebut menunjukkan bahwa ukuran perusahaan tidak memengaruhi manajemen dalam melakukan earnings management karena pada dasarnya yang mendorong terjadinya earnings management adalah manajer perusahaan itu sendiri, bukan besar kecilnya perusahaan tempatnya bekerja. Hasil penelitian ini bertentangan dengan penelitian Gunawan et al. (2014) yang menemukan bahwa size berpengaruh negatif signifikan terhadap earnings management.

\section{SIMPULAN, KETERBATASAN DAN SARAN}

\section{Simpulan}

Berikut ini adalah beberapa simpulan dalam penelitian ini:

1. Pada hipotesis pertama, variabel DISTRESS1, DISTRESS2 dan DISTRESS3 tidak berpengaruh signifikan terhadap earnings management. Sedangkan variabel ukuran perusahaan berpengaruh positif signifikan terhadap earnings management.

2. Pada hipotesis kedua, variabel DISTRESS3 dan variabel komisaris independen berpengaruh positif signifikan terhadap earnings management. Variabel interaksi antara financial distress dengan corporate governance berpengaruh negatif signifikan terhadap earnings management. Sedangkan variabel DISTRESS1, variabel DISTRESS2, variabel dewan direksi, variabel komite audit dan variabel ukuran perusahaan tidak berpengaruh signifikan terhadap earnings management.

\section{Keterbatasan Penelitian}

Beberapa keterbatasan dalam penelitian ini adalah: (1) periode pengamatan dalam penelitian ini hanya satu tahun; (2) jumlah sampel dalam penelitian ini hanya 62 perusahaan.

\section{Saran}

Saran yang perlu diperhatikan dalam mengembangkan dan memperluas penelitian ini adalah: 
1. Penelitian selanjutnya diharapkan dapat menambah jumlah sampel dengan menggunakan data laporan tahunan yang paling mutakhir agar dapat menggambarkan kondisi terkini.

2. Penelitian selanjutnya diharapkan dapat memperpanjang periode pengamatan untuk mendapatkan hasil yang lebih akurat.

3. Penelitian selanjutnya diharapkan dapat menambahkan variabel lain, misalnya variabel dewan komisaris dan kepemilikan institusional pada variabel moderasi serta variabel growth, leverage dan operating cash flow pada variabel kontrol agar mendapatkan hasil penelitian yang lebih baik dan dapat memperkaya ilmu pengetahuan.

4. Penelitian selanjutnya diharapkan dapat menggunakan model selain Jones model yang dianggap sebagai model terbaik dalam mendeteksi earnings management.

\section{DAFTAR PUSTAKA}

Bangun, Nurainun, dan Vincent. 2008. “Analisis hubungan komponen good corporate governance terhadap manajemen laba dengan kinerja keuangan pada perusahaan manufaktur yang terdaftar di bursa efek Indonesia.” Jurnal Akuntansi 12 (3): 239302.

Boediono, Gideon SB. 2005. "Kualitas laba: Studi pengaruh mekanisme corporate governance dan dampak manajemen laba dengan menggunakan analisis jalur." Simposium Nasional Akuntansi VIII, 172-94.

Brigham, E. F., dan P. R. Daves. 2003. Intermediate Financial Management. 9ed. United States of America: Thomson-South Western.

Chtourou, Sonda Marrakchi, Jean Bédard, dan Lucie Courteau. 2001. "Corporate governance and earnings management."

DeAngelo, Harry, Linda DeAngelo, dan Douglas J.Skinner. 1994. "Accounting choice in troubled companies." Journal of Accounting and Economics 17 (1): 113-43. https://doi.org/https://doi.org/10.1016/0165-4101(94)90007-8.

Emrinaldi, D. P. Nur. 2007. “Analisis pengaruh tata kelola perusahaan (corporate governance) terhadap kesulitan keuangan perusahaan (financial distress): Suatu kajian empiris." Jurnal Akuntansi dan Bisnis 9 (1): 88-108.

Fitdini. 2009. "Pengaruh corporate governance terhadap financial distress (studi pada perusahaan manufaktur yang listed di BEJ).” JKP XI, 236-47.

Ghozali, Imam. 2005. Aplikasi analisis multivariate dengan program SPSS. Semarang: Badan Penerbit Universitas Diponegoro.

2007. Aplikasi analisis multivariate dengan program SPSS. Semarang: Badan Penerbit Universitas Diponegoro.

Gumanti, Tatang Ary. 2003. "Motivasi di balik earnings management." Usahawan 12: 
$21-26$.

Gunawan, Fransisca Fortunata, Felizia Arni Rudiawarni, dan Aurelia C.C Sutanto. 2014. "Hubungan antara financial distress dengan earnings management pada badan usaha sektor manufaktur yang terdaftar di bei periode 2010-2012." Jurnal Ilmiah Mahasiswa Universitas Surabaya 3 (1): 1-18.

Healy, Paul M., dan James M. Wahlen. 1999. "A review of the earnings management literature and its implications for standard setting." Accounting Horizons 13 (4): 365-83. https://doi.org/10.2308/acch.1999.13.4.365.

Lin, Jerry W., June F. Li, dan Joon S. Yang. 2006. "The effect of audit committee performance on earnings quality." Managerial Auditing Journal 21 (9): 921-33. https://doi.org/10.1108/02686900610705019.

Millstein, I. M. 1999. "Report and recommendations of the blue ribbon committee on improving the effectiveness of corporate audit committees." The Business Lawyer 54 (3): 1067-95. https://doi.org/10.2307/40687876.

Monks, R, dan R Minow. 2001. Corporate governance. 2ed. Malden, MA: Blackwell Publisher.

Nasution, Marihot, dan Doddy Setiawan. 2007. "Pengaruh corporate governance terhadap manajemen laba di industri perbankan Indonesia." Simposium Nasional Akuntansi X, 1-26. https://doi.org/10.1016/B978-0-08-097086-8.73019-4.

Nuryaman. 2008. "Pengaruh konsentrasi kepemilikan, ukuran perusahaan, dan mekanisme corporate governance terhadap manajemen laba." Simposium Nasional Akuntansi XI.

Platt, H., dan M. B. Platt. 2002. "Predicting financial distress.” Journal of Financial Service Professionals 56: 12-15.

Rahmat, Mohd Mohid, Takiah Mohd Iskandar, dan Norman Mohd Saleh. 2009. "Audit committee characteristics in financially distressed and non-distressed companies." Managerial Auditing Journal 24 (7): 624-38. https://doi.org/10.1108/02686900910975350.

Rosner, Rebecca L. 2003. "Earnings manipulation in failing firms." Contemporary Accounting Research 20 (2): 361-408. https://doi.org/10.1506/8EVN-9KRB3AE4-EE81.

Schleifer, Andrei, dan Robert W. Vishny. 1997. "The limits of arbitrage." The Journal of Finance 52 (1): 35-55.

Scott, W. R. 2003. Financial accounting theory. 3ed. New Jersey: Prentice Hall Inc.

- 2009. Financial accounting theory. 5ed. Toronto: Pearson Prentice Hall.

Setiawati, L., dan Na’im. 2000. "Manajemen Laba.” Ekonomi dan Bisnis Indonesia 15 (4): 424-41. 
Siregar, Sylvia eronica N.P., dan Siddharta Utama. 2005. "Pengaruh struktur kepemilikan, ukuran perusahaan, dan praktek corporate governance terhadap pengelolaan laba (earnings management)." Simposium Nasional Akuntansi VIII, 475-90.

“The Indonesian Institute for Corporate Governance.” 2006. 2006.

Triwahyuningtias, Meilinda. 2012. "Analisis pengaruh struktur kepemilikan, ukuran dewan, komisaris independen, likuiditas, dan laverage terhadap terjadinya financial distress." Semarang, Universitas Diponogoro.

Ujiyantho, Muh. Arief, dan Bambang Agus Pramuka. 2007. "Mekanisme corporate governance, manajemen laba dan kinerja keuangan (studi pada perusahaan go publik sektor manufaktur)." Simposium Nasional Akuntansi X, 1-26.

Widari, L. K. 2004. “Analisis pengaruh proporsi dewan komisaris dan keberadaan komite audit terhadap manajemen laba." Simposium Nasional Akuntansi VII2 7.

Widyaningdyah, Agnes Utari. 2001. "Analisis Faktor-Faktor Yang Berpengaruh Terhadap Earnings Management Pada Perusahaan Go Public Di Indonesia." Jurnal Akuntansi dan Keuangan 3 (2): 89-101. 


\section{LAMPIRAN 1}

\section{UJI REGRESI EARNINGS MANAGEMENT}

Tabel 4.4

Variables Entered/Removed ${ }^{\text {a }}$

\begin{tabular}{cccc}
\hline Model & $\begin{array}{c}\text { Variables } \\
\text { Entered }\end{array}$ & $\begin{array}{c}\text { Variables } \\
\text { Removed }\end{array}$ & Method \\
\hline 1 & PPE_TA, & $\cdot$ & Enter \\
& REV_TA, I_TA ${ }^{\text {b }}$ & & \\
\hline
\end{tabular}

a. Dependent Variable: TACC_TA

b. All requested variables entered.

Tabel 4.5

Model Summary ${ }^{\mathrm{b}}$

\begin{tabular}{ccccc}
\hline Model & $\mathbf{R}$ & R Square & $\begin{array}{c}\text { Adjusted } \mathbf{R} \\
\text { Square }\end{array}$ & $\begin{array}{c}\text { Std. Error of the } \\
\text { Estimate }\end{array}$ \\
\hline 1 & $0,328^{\mathrm{a}}$ & 0,108 & 0,061 & 0,0653229618 \\
\hline
\end{tabular}

a. Predictors: (Constant), PPE_TA, REV_TA, I_TA

b. Dependent Variable: TACC_TA

Tabel 4.6

ANOVA ${ }^{\mathrm{a}}$

\begin{tabular}{llccccc}
\hline & Model & Sum of Squares & df & Mean Square & F & Sig. \\
\hline \multirow{4}{*}{1} & Regression & 0,030 & 3 & 0,010 & 2,331 & $0,084^{\mathrm{b}}$ \\
& Residual & 0,247 & 58 & 0,004 & & \\
& Total & 0,277 & 61 & & & \\
\hline
\end{tabular}

a. Dependent Variable: TACC_TA

b. Predictors: (Constant), PPE_TA, REV_TA, I_TA

Tabel 4.7

Coefficients $^{\mathrm{a}}$

\begin{tabular}{|c|c|c|c|c|c|}
\hline \multirow[t]{2}{*}{ Model } & \multicolumn{2}{|c|}{ Unstandardized Coefficients } & \multirow{2}{*}{$\begin{array}{c}\begin{array}{c}\text { Standardized } \\
\text { Coefficients }\end{array} \\
\text { Beta } \\
\end{array}$} & \multirow[t]{2}{*}{$\mathbf{t}$} & \multirow[t]{2}{*}{ Sig. } \\
\hline & $\mathbf{B}$ & Std. Error & & & \\
\hline & 0,010 & 0,016 & & 0,617 & 0,540 \\
\hline (Constant) & $-1376287417,048$ & 3632324495,687 & $-0,107$ & $-0,379$ & 0,706 \\
\hline I_TA & 0,012 & 0,044 & 0,073 & 0,263 & 0,793 \\
\hline REV_TA & $-0,100$ & 0,040 & $-0,325$ & $-2,525$ & 0,014 \\
\hline PPE_TA & & & & & \\
\hline
\end{tabular}

a. Dependent Variable: TACC_TA

Tabel 4.8

Residuals Statistics ${ }^{\mathrm{a}}$

\begin{tabular}{lccccc}
\hline & Minimum & Maximum & Mean & Std. Deviation & $\mathbf{N}$ \\
\hline Predicted Value & -.081064053 & .007505556 & -.023299108 & .0221195644 & 62 \\
Residual & -.1635324508 & .1471645683 & .0000000000 & .0636964087 & 62 \\
Std. Predicted Value & -2.611 & 1.393 & .000 & 1.000 & 62 \\
Std. Residual & -2.503 & 2.253 & .000 & .975 & 62 \\
\hline
\end{tabular}

a. Dependent Variable: TACC_TA 


\section{UJI ASUMSI KLASIK HIPOTESIS 1}

Tabel 4.9

Correlations

\begin{tabular}{clcccc}
\hline & & DISTRESS1 & DISTRESS2 & DISTRESS3 & SIZE \\
\hline \multirow{5}{*}{ DISTRESS1 } & Pearson Correlation & 1 & 0,173 & $0,393^{* *}$ & $-0,187$ \\
& Sig. (2-tailed) & & 0,180 & 0,002 & 0,146 \\
& $\mathrm{~N}$ & 62 & 62 & 62 & 62 \\
& Pearson Correlation & 0,173 & 1 & $0,616^{* *}$ & 0,123 \\
DISTRESS2 & Sig. (2-tailed) & 0,180 & & 0,000 & 0,342 \\
& N & 62 & 62 & 62 & 62 \\
& Pearson Correlation & $0,393^{* *}$ & $0,616^{* *}$ & 1 & 0,189 \\
DISTRESS3 & Sig. (2-tailed) & 0,002 & 0,000 & & 0,141 \\
& N & 62 & 62 & 62 & 62 \\
& Pearson Correlation & $-0,187$ & 0,123 & 0,189 & 1 \\
& Sig. (2-tailed) & 0,146 & 0,342 & 0,141 & 62 \\
\hline *** Correlation & $\mathrm{N}$ & 62 & 62 & 62 & 62
\end{tabular}

**. Correlation is significant at the 0.01 level (2-tailed).

\section{UJI REGRESI HIPOTESIS 1}

Tabel 4.10

Variables Entered/Removed ${ }^{\mathrm{a}}$

\begin{tabular}{|c|c|c|c|}
\hline Model & Variables Entered & Variables Removed & Method \\
\hline 1 & $\begin{array}{lr}\text { SIZE, } & \text { DISTRESS2, } \\
\text { DISTRESS1, DISTRESS3 }\end{array}$ & & Enter \\
\hline
\end{tabular}

a. Dependent Variable: DACC

b. All requested variables entered.

Tabel 4.11

Model Summary ${ }^{b}$

\begin{tabular}{cccccc}
\hline Model & $\mathbf{R}$ & R Square & $\begin{array}{c}\text { Adjusted } \mathbf{R} \\
\text { Square }\end{array}$ & $\begin{array}{c}\text { Std. Error of the } \\
\text { Estimate }\end{array}$ & Durbin-Watson \\
\hline 1 & $0,458^{\mathrm{a}}$ & 0,210 & 0,154 & 0,05857151 & 2,057 \\
\hline
\end{tabular}

a. Predictors: (Constant), SIZE, DISTRESS2, DISTRESS1, DISTRESS3

b. Dependent Variable: DACC

Tabel 4.12

ANOVA ${ }^{a}$

\begin{tabular}{llccccc}
\hline & Model & Sum of Squares & df & Mean Square & F & Sig. \\
\hline \multirow{4}{*}{1} & Regression & 0,052 & 4 & 0,013 & 3,785 & $0,008^{\mathrm{b}}$ \\
& Residual & 0,196 & 57 & 0,003 & & \\
& Total & 0,247 & 61 & & & \\
\hline
\end{tabular}

a. Dependent Variable: DACC

b. Predictors: (Constant), SIZE, DISTRESS2, DISTRESS1, DISTRESS3 


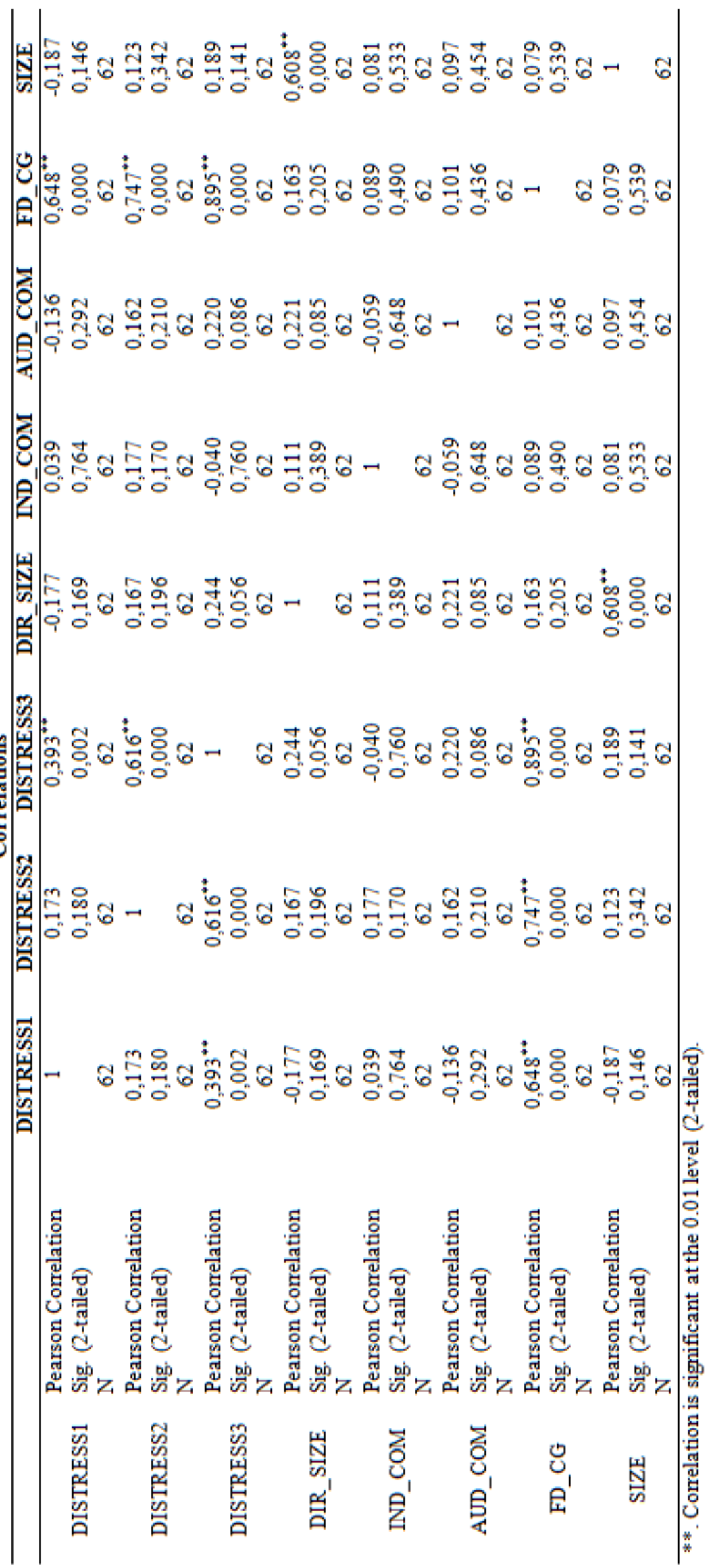




\section{UJI REGRESI HIPOTESIS 2}

Tabel 4.14

Variables Entered/Removed ${ }^{\text {a }}$

\begin{tabular}{clcc}
\hline Model & Variables Entered & $\begin{array}{c}\text { Variables } \\
\text { Removed }\end{array}$ & Method \\
\hline \multirow{2}{*}{1 SIZE, FD_CG, } & $\cdot$ & Enter \\
& IND_COM, & \\
& AUD_COM, & \\
& DIR_SIZE, & \\
& DISTRESS1, & \\
& DISTRESS2, & \\
& DISTRESS3 ${ }^{\mathrm{b}}$ & \\
\hline
\end{tabular}

a. Dependent Variable: DACC

b. All requested variables entered.

Tabel 4.15

Model Summary ${ }^{b}$

\begin{tabular}{cccccc}
\hline Model & $\mathbf{R}$ & R Square & $\begin{array}{c}\text { Adjusted R } \\
\text { Square }\end{array}$ & $\begin{array}{c}\text { Std. Error of the } \\
\text { Estimate }\end{array}$ & Durbin-Watson \\
\hline 1 & $.667^{\mathrm{a}}$ & .445 & .362 & .05089194 & 1.903 \\
\hline
\end{tabular}

a. Predictors: (Constant), SIZE, FD_CG, IND_COM, AUD_COM, DIR_SIZE, DISTRESS1, DISTRESS2, DISTRESS3

b. Dependent Variable: DACC

Tabel 4.16

ANOVA ${ }^{a}$

\begin{tabular}{llccccc}
\hline & Model & Sum of Squares & df & Mean Square & F & Sig. \\
\hline \multirow{4}{*}{1} & Regression & .110 & 8 & .014 & 5.320 & $.000^{\mathrm{b}}$ \\
& Residual & .137 & 53 & .003 & & \\
& Total & .247 & 61 & & & \\
\hline
\end{tabular}

a. Dependent Variable: DACC

b. Predictors: (Constant), SIZE, FD_CG, IND_COM, AUD_COM, DIR_SIZE, DISTRESS1, DISTRESS2, DISTRESS3 


\section{LAMPIRAN 2}

Tabel 4.17

Uji Kolmogorov-Smirnov

\begin{tabular}{|c|c|c|}
\hline & & Unstandardized Residual \\
\hline $\mathrm{N}$ & & 62 \\
\hline \multirow{3}{*}{ Normal Parameters ${ }^{\mathrm{a}, \mathrm{b}}$} & Mean & 0,0000000 \\
\hline & Std. Deviation & 0,05661857 \\
\hline & Absolute & 0,110 \\
\hline \multirow[t]{2}{*}{ Most Extreme Differences } & Positive & 0,110 \\
\hline & Negatif & $-0,110$ \\
\hline Kolmogorov-Smirnov Z & & 0,869 \\
\hline Asymp. Sig. (2-tailed) & & 0,437 \\
\hline
\end{tabular}

a. Test distribution is Normal.

b. Calculated from data.

TABEL 4.18

One-Sample Kolmogorov-Smirnov Test

\begin{tabular}{|c|c|c|}
\hline & & Unstandardized Residual \\
\hline$\overline{\mathrm{N}}$ & & 62 \\
\hline \multirow{3}{*}{ Normal Parameters ${ }^{\mathrm{a}, \mathrm{b}}$} & Mean & 0,0000000 \\
\hline & Std. Deviation & 0,04743752 \\
\hline & Absolute & 0,093 \\
\hline \multirow[t]{2}{*}{ Most Extreme Differences } & Positive & 0,085 \\
\hline & Negatif & $-0,093$ \\
\hline Kolmogorov-Smirnov Z & & 0,735 \\
\hline Asymp. Sig. (2-tailed) & & 0,652 \\
\hline
\end{tabular}

a. Test distribution is Normal.

b. Calculated from data. 


\section{LAMPIRAN 3}

Tabel 4.19

Coefficients $^{\mathrm{a}}$

\begin{tabular}{rlccccc}
\hline \multirow{2}{*}{ Model } & \multicolumn{2}{c}{ Unstandardized Coefficients } & $\begin{array}{c}\text { Standardized } \\
\text { Coefficients }\end{array}$ & \multirow{2}{*}{ t } & \multirow{2}{*}{ Sig. } \\
\cline { 2 - 5 } & B & Std. Error & Beta & & \\
\hline \multirow{2}{*}{1} & (Constant) & 0,122 & 0,083 & & 1,466 & 0,148 \\
& DISTRESS1 & 0,000 & 0,015 & 0,003 & 0,020 & 0,984 \\
& DISTRESS2 & $-0,024$ & 0,024 & $-0,165$ & $-1,000$ & 0,322 \\
& DISTRESS3 & 0,049 & 0,041 & 0,217 & 1,190 & 0,239 \\
& SIZE & $-0,007$ & 0,007 & $-0,137$ & $-0,991$ & 0,326 \\
\hline
\end{tabular}

a. Dependent Variable: AbsUt

Tabel 4.20

Coefficients $^{\mathrm{a}}$

\begin{tabular}{|c|c|c|c|c|c|c|}
\hline & \multirow[t]{2}{*}{ Model } & \multicolumn{2}{|c|}{ Unstandardized Coefficients } & \multirow{2}{*}{$\begin{array}{c}\begin{array}{c}\text { Standardized } \\
\text { Coefficients }\end{array} \\
\text { Beta }\end{array}$} & \multirow[t]{2}{*}{$\mathbf{t}$} & \multirow[t]{2}{*}{ Sig. } \\
\hline & & B & Std. Error & & & \\
\hline \multirow{9}{*}{1} & (Constant) & 0,163 & 0,079 & & 2,063 & 0,044 \\
\hline & DISTRESS1 & $-0,016$ & 0,037 & $-0,191$ & $-0,426$ & 0,672 \\
\hline & DISTRESS2 & $-0,043$ & 0,049 & $-0,370$ & $-0,879$ & 0,383 \\
\hline & DISTRESS3 & $-0,042$ & 0,110 & $-0,238$ & $-0,386$ & 0,701 \\
\hline & DIR_SIZE & 0,000 & 0,003 & $-0,018$ & $-0,099$ & 0,922 \\
\hline & IND_COM & $-0,036$ & 0,032 & $-0,150$ & $-1,113$ & 0,271 \\
\hline & AUD_COM & $-0,018$ & 0,010 & $-0,267$ & $-1,936$ & 0,058 \\
\hline & FD_CG & 0,002 & 0,005 & 0,528 & 0,475 & 0,637 \\
\hline & SIZE & $-0,004$ & 0,006 & $-0,119$ & $-0,724$ & 0,472 \\
\hline
\end{tabular}

a. Dependent Variable: AbsUt 


\section{LAMPIRAN 4}

Tabel 4.21

Model Summary ${ }^{\mathbf{b}}$

\begin{tabular}{cccccc}
\hline Model & \multirow{2}{*}{ R Square } & $\begin{array}{c}\text { Adjusted } \mathbf{R} \\
\text { Square }\end{array}$ & $\begin{array}{c}\text { Std. Error of the } \\
\text { Estimate }\end{array}$ & Durbin-Watson \\
\hline 1 & $0,458^{\mathrm{a}}$ & 0,210 & 0,154 & 0,05857151 & 2,057 \\
\hline
\end{tabular}

a. Predictors: (Constant), SIZE, DISTRESS2, DISTRESS1, DISTRESS3

b. Dependent Variable: DACC

Tabel 4.22

Model Summary ${ }^{\mathbf{b}}$

\begin{tabular}{cccccc}
\hline Model & $\mathbf{R}$ & R Square & $\begin{array}{c}\text { Adjusted } \mathbf{R} \\
\text { Square }\end{array}$ & $\begin{array}{c}\text { Std. Error of the } \\
\text { Estimate }\end{array}$ & Durbin-Watson \\
\hline 1 & $0,667^{\mathrm{a}}$ & 0,445 & 0,362 & 0,05089194 & 1,903 \\
\hline
\end{tabular}

a. Predictors: (Constant), SIZE, FD_CG, IND_COM, AUD_COM, DIR_SIZE,

DISTRESS1, DISTRESS2, DISTRESS3

b. Dependent Variable: DACC

Tabel 4.23

Coefficients $^{\mathrm{a}}$

\begin{tabular}{ccccccc}
\hline \multirow{2}{*}{ Model } & \multicolumn{2}{c}{ Unstandardized Coefficients } & $\begin{array}{c}\text { Standardized } \\
\text { Coefficients }\end{array}$ & t & Sig. \\
\cline { 2 - 5 } & B & Std. Error & Beta & & \\
\hline \multirow{2}{*}{1} & (Constant) & $-0,239$ & 0,120 & & $-1,985$ & 0,052 \\
& DISTRESS1 & $-0,036$ & 0,022 & $-0,215$ & $-1,602$ & 0,115 \\
& DISTRESS2 & $-0,030$ & 0,035 & $-0,129$ & $-0,856$ & 0,395 \\
& DISTRESS3 & $-0,053$ & 0,059 & $-0,148$ & $-0,894$ & 0,375 \\
& SIZE & 0,020 & 0,010 & 0,262 & 2,090 & 0,041 \\
\hline
\end{tabular}

a. Dependent Variable: DACC

Tabel 4.24

Coefficients $^{\mathrm{a}}$

\begin{tabular}{ccccccc}
\hline \multirow{2}{*}{ Model } & \multicolumn{2}{c}{ Unstandardized Coefficients } & $\begin{array}{c}\text { Standardized } \\
\text { Coefficients }\end{array}$ & t & Sig. \\
\cline { 2 - 5 } & B & Std. Error & Beta & & \\
\hline & (Constant) & $-0,194$ & 0,130 & & $-1,498$ & 0,140 \\
& DISTRESS1 & 0,117 & 0,061 & 0,707 & 1,923 & 0,060 \\
& DISTRESS2 & 0,150 & 0,080 & 0,647 & 1,876 & 0,066 \\
& DISTRESS3 & 0,497 & 0,181 & 1,389 & 2,746 & 0,008 \\
1 & DIR_SIZE & 0,003 & 0,004 & 0,120 & 0,810 & 0,422 \\
& IND_COM & 0,227 & 0,053 & 0,474 & 4,275 & 0,000 \\
& AUD_COM & $-0,017$ & 0,016 & $-0,122$ & $-1,084$ & 0,283 \\
& FD_CG & $-0,024$ & 0,008 & -20616 & $-2,871$ & 0,006 \\
& SIZE & 0,012 & 0,010 & 0,157 & 1,168 & 0,248 \\
\hline
\end{tabular}

Dependent Variable: DACC 
Tabel 4.25

Coefficients $^{\mathrm{a}}$

\begin{tabular}{ccccccc}
\hline \multirow{2}{*}{ Model } & \multicolumn{2}{c}{ Unstandardized Coefficients } & $\begin{array}{c}\text { Standardized } \\
\text { Coefficients }\end{array}$ & \multirow{2}{*}{ t } & \multirow{2}{*}{ Sig. } \\
\cline { 2 - 5 } & B & Std. Error & Beta & & \\
\hline \multirow{2}{*}{1} & (Constant) & $-0,239$ & 0,120 & & $-1,985$ & 0,052 \\
& DISTRESS1 & $-0,036$ & 0,022 & $-0,215$ & $-1,602$ & 0,115 \\
& DISTRESS2 & $-0,030$ & 0,035 & $-0,129$ & $-0,856$ & 0,395 \\
& DISTRESS3 & $-0,053$ & 0,059 & $-0,148$ & $-0,894$ & 0,375 \\
& SIZE & 0,020 & 0,010 & 0,262 & 2,090 & 0,041 \\
\hline
\end{tabular}

a. Dependent Variable: DACC

Tabel 4.26

Coefficients $^{\mathrm{a}}$

\begin{tabular}{|c|c|c|c|c|c|c|}
\hline & \multirow[t]{2}{*}{ Model } & \multicolumn{2}{|c|}{ Unstandardized Coefficients } & \multirow{2}{*}{$\begin{array}{c}\begin{array}{c}\text { Standardized } \\
\text { Coefficients }\end{array} \\
\text { Beta }\end{array}$} & \multirow[t]{2}{*}{$\mathbf{t}$} & \multirow[t]{2}{*}{ Sig. } \\
\hline & & B & Std. Error & & & \\
\hline \multirow{9}{*}{1} & (Constant) & $-0,194$ & 0,130 & & $-1,498$ & 0,140 \\
\hline & DISTRESS 1 & 0,117 & 0,061 & 0,707 & 1,923 & 0,060 \\
\hline & DISTRESS2 & 0,150 & 0,080 & 0,647 & 1,876 & 0,066 \\
\hline & DISTRESS3 & 0,497 & 0,181 & 1,389 & 2,746 & 0,008 \\
\hline & DIR_SIZE & 0,003 & 0,004 & 0,120 & 0,810 & 0,422 \\
\hline & IND_COM & 0,227 & 0,053 & 0,474 & 4,275 & 0,000 \\
\hline & AUD_COM & $-0,017$ & 0,016 & $-0,122$ & $-1,084$ & 0,283 \\
\hline & FD_CG & $-0,024$ & 0,008 & -20616 & $-2,871$ & 0,006 \\
\hline & SIZE & 0,012 & 0,010 & 0,157 & 1,168 & 0,248 \\
\hline
\end{tabular}

a. Dependent Variable: DACC 
